\title{
Use of combined therapy (TENS+UD) and postisometric relaxation (PIR) of muscles in seniors with degenerative disease of the hip joint
}

\author{
Magdalena Podczarska-Głowacka', Anna Łysak ${ }^{1}$ \\ ${ }^{1}$ Department of Physiotherapy, University of Gdansk, Poland
}

Podczarska-Głowacka M, Łysak A. Use of combined therapy (TENS+UD) and postisometric relaxation (PIR) of muscles in seniors with degenerative disease of the hip joint. J Pre-Clin Clin Res. 2016; 10(2): 95-99. doi: 10.5604/18982395.1227564

\begin{abstract}
Objective. The aim of the study was to assess the effectiveness of a combined therapy (TENS+UD) and postisometric relaxation of muscles in a 3-week therapeutic programme directed to seniors with diagnosed degenerative disease of the hip joint (OA).

Materials and method. The study involved patients with diagnosed degenerative disease of the hip joint. A total of 60 people - 11 men and 49 women (mean age - 68 years) were examined. The therapy was applied for a period of 3 weeks. Seniors were randomly divided into 2 equal groups. In Group I, the treatment programme included a combined therapy (TENS+UD) and individual exercises, i.e. postisometric relaxation of muscles (PIR) at the hip joint; in Group II, seniors were treated with individual exercises, i.e. postisometric relaxation of muscles (PIR).

Results. The study showed that the applied therapeutic programme had a significant effect. In both groups an improvement in mobility after the therapy was shown in all planes of movement. It was also found that the therapy proved effective in fighting pain syndromes. However, it should be noted that after assessing pain twice (VAS, Laitinen Scale) in Group I, the therapy proved to be more effective in fighting pain in comparison to Group II.

Conclusions. In non-invasive treatment, in order to increase the analgesic activity in patients with degenerative changes of the hip joint, it is also recommended to include a physical stimulus in the form of combined therapy in the physiotherapeutic procedure, comprising techniques of energising muscles.
\end{abstract}

\section{Key words}

degenerative changes of the hip joint, combined therapy (TENS+UD), postisometric relaxation of muscles, mobility of the hip joint, pain syndromes

\section{INTRODUCTION}

An increasing interest in the issues of old age is due to the progressive ageing of society, and increasing participation of older people in the overall social structure. The phenomenon of ageing of the population, and simultaneously extending life expectancy, by far concerns the developed countries, and is connected, among others, with the declining number of births and a generally viewed increase in prosperity: living and housing conditions, social activity, increased general and health awareness, easier access to medical benefits and social welfare. For elderly people, old age is something real, affecting them personally [1]. Undoubtedly, the prolongation of life expectancy is accompanied by increasing (all kinds of) health problems [2]. Osteoarthritis (OA), including the degenerative disease of the hip joint, is one of the most common old-age ailments concerning $50 \%$ of the population aged over 65 years [3]. Physiotherapeutic treatment of degenerative changes is a complex process. This may result from the the duration of the disease, but also because of a lack of a therapeutic regimen in patient management and negligence in the sphere of prophylaxis [4]. Pain syndromes accompanying the development of the disease, restrictions in

Address for correspondence: Magdalena Podczarska-Głowacka, Katedra Fizjoterapii, AWFiS Gdańsk, Hoża 11H/7, 80-628 Gdańsk, Poland

E-mail: magdapodczarska@awf.gda.pl

Received: 05 October 2015; accepted: 18 July 2016 articular mobility, deterioration in general balance, overall fitness and efficiency as well as co-existing diseases, only increase functional limitations, thus affecting the increase in disability. The consequences can be somewhat minimized by involving seniors in an individually selected therapeutic programme that would enable active functioning foras long as possible, with the preservation of autonomy and independence $[4,5]$.

In geriatrics, attention is drawn to drug-free procedure methods, due to the small risk of undesirable consequences [6]. These include kinesitherapy, physical therapy and soft tissue techniques, as well as educating the patient and his/her family and choosing appropriate rehabilitation to provide self-help [7]. Numerous studies stress the particular importance of kinesitherapy and physical therapy as very effective and affordable forms of behavioural therapy in alleviating pain and improving mobility and, consequently, in improving the functional activities in osteoarthritis of the hip joint [8].

One of the methods using a physical stimulus to relieve pain in the degenerative disease is the combined therapy joining the effect of pulse currents of small or medium frequency and ultrasonic wave (UD) [9]. In the combined therapy, the hyperaemic and relaxing influence of ultrasound combined with an analgesic and hyperemic influence of electric current causes analgesia, decreased muscle tone and a local improvement in tissue trophism. In addition, 
the combination of electrotherapy and ultrasound increases the sensitivity of the sensory receptors of the skin, which results in a better sensation of the current by the patient [10, 11]. An electric stimulus can be transcutaneous electrical nerve stimulation (TENS) through premodulated medium frequency currents $[9,10,12]$. TENS electrical stimulation is the most widely-used analgesic treatment [13]. In TENS, the analgesic effect is achieved by activation of the nervous system mechanisms that control pain sensations at the level of the spinal cord, as well as by an increased production of endorphins [11]. It is reported that the advantage of the combined therapy over traditional physical procedures lies in the fact of conducting treatment on an individual basis, on each patient by means of a moveable ultrasound head. This provides the possibility of working accurately and reliably on the affected structures with a very small dose of current, as ultrasounds increase the sensitivity of nerve fibres [11]. The optimal conduct of the comprehensive therapy also includes the use of appropriately selected techniques of muscle energy, including postisometric relaxation of muscles (PIR), in order to restore the correct length and elasticity of muscle fibres and thus restore, as far as possible, the proper range of motion in the hip joint [14]. It has been proved in extensive scientific research that carefully selected therapeutic exercises, as well as manipulations and mobilizations, can reverse the decline in articular mobility. In addition, a combination of the above-mentioned techniques with streatching may result in an improvement in articular dysfunctions in persons with osteoarthritis of the hip $[14,15]$.

\section{OBJECTIVE}

The aim of this study was to assess the effectiveness of procedures of a combined therapy (TENS+UD) and postisometric relaxation of muscles in a proposed 3-week therapeutic programme addressed to seniors with diagnosed degenerative disease of the hip joint $(\mathrm{OA})$.

\section{MATERIALS AND METHODS}

The study was conducted at the Nadmorskie Centrum Medyczne in Gdansk and at Gdansk University of Physical Education and Sport. A total of 60 seniors were examined 11 men and 49 women, with clinically and radiographically diagnosed degenerative disease of the hip joint. At the beginning of the observation, the mean age of all persons involved in the therapeutic programme was 68 years, with the standard deviation of 7.8 years (Tab. 1). The patients were chosen intentionally, according to specific criteria. The selection criteria for the scientific experiment included: clinically and radiographically diagnosed coxarthrosis of one or both hip joints, morning stiffness, consent to participate in the research, a fixed and unchangeable during the therapy dose of medication during pharmacological treatment. Exclusion criteria for the scientific study included: patients after hip replacement surgery, intra-articular or other systemic steroid received in the last month.

On the basis of the above-mentioned selection and exclusions criteria, 2 research groups research groups, equal in, were randomly assigned. The first group comprised patients whose medical programme involved a combined therapy
Table 1. Baseline characteristics of patients included in the study

\begin{tabular}{lccc}
\hline & Group I & Group II & Both \\
\hline Total No. of patients & 30 & 30 & 60 \\
\hline Females/males (No.) & $23 / 7$ & $26 / 4$ & $49 / 11$ \\
\hline Age, mean \pm SD years & $67.8 \pm 6.6$ & $68.3 \pm 9.0$ & $68.0 \pm 7.8$ \\
\hline Age, females, mean \pm SD years & $67.0 \pm 7.0$ & $67.8 \pm 9.5$ & $67.5 \pm 8.4$ \\
\hline Age, males, mean \pm SD years & $70.3 \pm 4.9$ & $71.2 \pm 3.8$ & $70.6 \pm 4.4$ \\
\hline
\end{tabular}

(TENS+UD) and individual exercises, i.e. postisometric relaxation of muscles (PIR) at the hip joint. In the second group, seniors were treated with individual exercises, i.e. postisometric relaxation of muscles (PIR) (Fig. 1).

\begin{tabular}{|c|c|}
\hline \multicolumn{2}{|c|}{ Assessed for eligibility } \\
\hline \multicolumn{2}{|c|}{ Randomised ( $\mathrm{n}=60$ ) } \\
\hline \multicolumn{2}{|c|}{ Allocation } \\
\hline $\begin{array}{l}\text { Allocated to Group I } \\
\qquad(\mathrm{n}=\mathbf{3 0})\end{array}$ & $\begin{array}{l}\text { Allocated to Group II } \\
\qquad(\mathrm{II}=30)\end{array}$ \\
\hline Combined therapy (TENS and UD) + PIR & PIR \\
\hline Received intervention $(n=30)$ & Received intervention ( $\mathrm{n}=30$ ) \\
\hline Did not receive intervention ( $\mathrm{n}=0$ ) & Did not teceive intervention $(\mathrm{n}=0)$ \\
\hline At 3 weeks & At 3 weeks \\
\hline Follow up: 30 & Follow up: 30 \\
\hline Analysed $(n=30)$ & Analysed $(\mathrm{n}=30)$ \\
\hline
\end{tabular}

Figure 1. Patient participation flow in the study

The therapeutic programme was conducted for a period of 3 weeks on an outpatient basis. The duration of each session was similar and lasted about 40 minutes. The examination was made twice, before and after the therapy. To assess the severity of pain, 2 research tools were used - the VisualAnalogue Scale (VAS) and a shortened pain questionnaire according to Laitinen $[16,17]$. The first scale is a method commonly used clinical practice and statistical research. Determining the subjective pain intensity by means of the visual-analogue scale VAS was based on drawing a mark on a 10-centrimetre line by the patient. The beginning of the line, point zero, meant no pain, while the end - the strongest felt or imagineable pain, i.e. the maximal pain [16]. The patient defined the intensity of his/her ailments in a specific sequence. The second subjective pain scale was a shortened questionnaire according to Laitinen, which was used to specify the pain perceived by patients in greater detail. The patient marked the most recent answer relating to the perceived pain on a 5-point scale [17]. The questionnaire sequences pertained to the level of severity, the frequency of the severity of pain, and the frequency of the use of painkillers.

The measurement of the hip joint mobility was taken in 3 planes: sagittal (flexion and extension), frontal (abducting and adducting) and transverse (external and internal rotation movement). The initial positions for testing were chosen in accordance with the ISOM-SFTR methodology (International SFTR Method of Measuring and Recording Joint Motion, International Standard Orthopedic Measurements) [18]. The measurements were made using a goniometer. 
The combined therapy was performed with a use of a device which allowed parallel application of an ultrasonic wave (UD) and alternating pulse current (TENS). All patients in Group I were given bi-directional, triangular, symmetric current TENS with the pulse frequency of $80-100 \mathrm{~Hz}$ and pulse duration of $100 \mu$ s. Simultaneously, ultrasounds with the frequency of $1 \mathrm{MHz}$ were used. An impulse wave with a fill factor of $50 \%$ was used. The average was $0.7 \mathrm{~W} / \mathrm{cm}^{2}$ of the sonication surface. The ultrasonic head connected to the negative pole (cathode) placed on the affected hip joint constituted the active electrode in the combined therapy. The passive electrode (anode) was a plate electrode made of conductive carbon rubber of thedimensions $6 \mathrm{~cm} \mathrm{x} 6 \mathrm{~cm}$. The passive electrode was placed paraspinally at the height of the lumbar spine, on the same side as the degenerative hip. The combined treatment was performed with the active electrode (ultrasonic head), with a dynamic method around the greater trochanter of the damaged hip joint. The duration of a single treatment was 8 minutes. The amperage was adjusted to the patient's individual sensation (pleasant, clear tingling) without the feeling of pain and muscle contractions. The treatment was applied in the lying position.

In order to improve the range of motion at the hip joint in the applied procedure, postisometric relaxation was used on the following muscles: extensors, flexors, abductors, adductors, internal and external rotators of the hip joint. Therapy of the aforementioned muscles was carried out on an individual basis. Postisometric relaxation of muscles (PIR) was performed repeatedly, where 1 cycle consisted of 3 phases. During the first phase, muscles were stretched until light pain or a feeling of slight stretching of the exercised muscle group or muscle was experienced. The second phase consisted in isometric flexion of muscles which lasted for 8-10 seconds, after which the third phase took place. In the third phase, there was total relaxation of muscles with restretching of the exercised muscle group. The whole cycle was repeated from 3-5 times. The duration of each session was about 30 minutes. In addition, therapy in both the first and the second group was enhanced with instructions on how to perform exercises at home by a senior. The authors took care that the patient finishing a therapeutic programme could exercise independently at home.

\section{RESULTS}

The results of the study were developed using statistical package Statistica ver. 10.0. To verify the significance of differences between groups in which the different types of treatments were applied, ANOVA analysis of variance tool with repeated measurements was used. Statistical significance was set at $\mathrm{p}<0.05$.

Analysis of data before and after the therapy in groups in which 2 different physiotherapeutic procedures were implemented, namely, the combined therapy (TENS+UD) plus postisometric relaxation of muscles (PIR) (Group I) and only postisometric relaxation of muscles (PIR) (Group II), revealed statistically significant differences $(p<0.05)$ for the following measurements: pain ailments in their intensity and the frequency of occurrence, taking painkillers, and the range of motion at the hip joint in the sagittal, frontal and transverse planes (Tab. 2). The obtained analgesic effect was confirmed by a decrease in the mean value of pain
Table 2. Changes in the range of motion and intensity of pain in patients before and after therapy in Group I and Group II

\begin{tabular}{|c|c|c|c|c|c|}
\hline Group & Variable & $\begin{array}{c}\text { Pre- } \\
\text { treatment } \\
\text { Mean } \pm \text { SD }\end{array}$ & $\begin{array}{c}\text { Post- } \\
\text { treatment } \\
\text { Mean } \pm \text { SD }\end{array}$ & P-value & $\begin{array}{l}\text { Sig- } \\
\text { nifi- } \\
\text { cance }\end{array}$ \\
\hline \multirow{10}{*}{ Group I } & ROM, degrees, flexion & $59.0 \pm 12.41$ & $71.0 \pm 16.45$ & 0.0001 & $\mathrm{~S}$ \\
\hline & ROM, degrees, extension & $6.0 \pm 1.3$ & $8.8 \pm 1.2$ & 0.0001 & $\mathrm{~S}$ \\
\hline & ROM, degrees, adduction & $18.1 \pm 4.65$ & $23.5 \pm 5.1$ & 0.0001 & $\mathrm{~S}$ \\
\hline & ROM, degrees, abduction & $17.1 \pm 2.9$ & $23.0 \pm 4.1$ & 0.0001 & $\mathrm{~S}$ \\
\hline & $\begin{array}{l}\text { ROM, degrees, external } \\
\text { rotation }\end{array}$ & $26.3 \pm 4.2$ & $31.0 \pm 4.3$ & 0.0001 & $\mathrm{~S}$ \\
\hline & $\begin{array}{l}\text { ROM, degrees, internal } \\
\text { rotation }\end{array}$ & $24.1 \pm 4.9$ & $28.7 \pm 5.3$ & 0.0001 & $\mathrm{~S}$ \\
\hline & VAS scale & $5.6 \pm 1.8$ & $3.3 \pm 1.7$ & 0.0001 & $\mathrm{~S}$ \\
\hline & $\begin{array}{l}\text { Intensity of pain on the } \\
\text { Laitinen scale }\end{array}$ & $2.1 \pm 0.7$ & $1.0 \pm 0.5$ & 0.0001 & $\mathrm{~S}$ \\
\hline & $\begin{array}{l}\text { Frequency of pain on the } \\
\text { Laitinen scale }\end{array}$ & $2.1 \pm 0.7$ & $0.8 \pm 0.5$ & 0.0001 & $\mathrm{~S}$ \\
\hline & $\begin{array}{l}\text { Application of painkillers } \\
\text { on the Laitinen scale }\end{array}$ & $1.5 \pm 0.7$ & $0.6 \pm 0.5$ & 0.0001 & $\mathrm{~S}$ \\
\hline \multirow{10}{*}{ Group II } & ROM, degrees, flexion & $62.7 \pm 15.6$ & $68 \pm 15.5$ & 0.0003 & $\mathrm{~S}$ \\
\hline & ROM, degrees, extension & $5.8 \pm 1.5$ & $8.4 \pm 1.3$ & 0.0001 & $\mathrm{~S}$ \\
\hline & ROM, degrees, adduction & $18.3 \pm 3.2$ & $22.9 \pm 3.1$ & 0.0001 & $\mathrm{~S}$ \\
\hline & ROM, degrees, abduction & $17.1 \pm 4.1$ & $21.7 \pm 4.6$ & 0.0001 & $\mathrm{~S}$ \\
\hline & $\begin{array}{l}\text { ROM, degrees, external } \\
\text { rotation }\end{array}$ & $24.7 \pm 3.9$ & $29.8 \pm 4.2$ & 0.0001 & $\mathrm{~S}$ \\
\hline & $\begin{array}{l}\mathrm{ROM} \text {, degrees, internal } \\
\text { rotation }\end{array}$ & $23.2 \pm 3.8$ & $28.0 \pm 4.2$ & 0.0001 & $\mathrm{~S}$ \\
\hline & VAS scale & $6.3 \pm 1.9$ & $4.7 \pm 1.7$ & 0.0001 & $S$ \\
\hline & $\begin{array}{l}\text { Intensity of pain on the } \\
\text { Laitinen scale }\end{array}$ & $2.3 \pm 0.7$ & $1.6 \pm 0.5$ & 0.0001 & $S$ \\
\hline & $\begin{array}{l}\text { Frequency of pain on the } \\
\text { Laitinen scale }\end{array}$ & $2.1 \pm 0.8$ & $1.3 \pm 0.7$ & 0.0001 & $S$ \\
\hline & $\begin{array}{l}\text { Application of painkillers } \\
\text { on the Laitinen scale }\end{array}$ & $1.9 \pm 0.7$ & $1.6 \pm 0.6$ & 0.0041 & $S$ \\
\hline
\end{tabular}

P-value = Probability $\quad$ S = Significant $\quad$ NS = Non-significant

ailments in Groups I and II, according to the VAS scale. According to Laitinen's questionnaire, the feeling of pain and its frequency decreased, on average, by about one point in all the subjects. Analysis of results showed a significant decrease in the value of the variable - using analgesics and anti-inflammatory drugs after completing the therapy, in comparison to the situation before treatment. Before the therapy, a decline in mobility of the hip joint had been found among all patients. The average values of the range of motion in the sagittal, frontal and transverse planes at the hip joint after the treatment were statistically significantly $(\mathrm{p}<0.01)$ improved (Tab. 2).

In both groups before the treatment, the evaluated parameters were comparable and the differences between them statistically insignificant (Tab. 3). The applied procedures increased the range of motion at the hip joint in the sagittal, frontal and transverse planes in both groups. Differences in mean values between groups after completing the therapy were statistically insignificant. However, statistically significant were differences between values specifying the degree of theintensity of pain disorders - 3.3 \pm 1.7 (Group I) vs $4.7 \pm 1.7$ (Group II), according to the VAS scale; $1.1 \pm 0.5$ (Group I) vs. 1.6 \pm 0.5 (Group II), according to the Laitinen 
Table 3. Comparison of research results between groups before and after therapy

\begin{tabular}{|c|c|c|c|c|c|}
\hline $\begin{array}{l}\text { Time of } \\
\text { measure- } \\
\text { ments }\end{array}$ & Variable & $\begin{array}{c}\text { Group I } \\
\text { Mean } \pm \text { SD }\end{array}$ & $\begin{array}{c}\text { Group II } \\
\text { Mean } \pm S D\end{array}$ & P-value & $\begin{array}{l}\text { Sig- } \\
\text { nifi- } \\
\text { cance }\end{array}$ \\
\hline \multirow{10}{*}{$\begin{array}{l}\text { Pre- } \\
\text { treatment }\end{array}$} & ROM, degrees, flexion & $59.0 \pm 12.41$ & $62.7 \pm 15.6$ & 0.783 & NS \\
\hline & ROM, degrees, extension & $6.0 \pm 1.3$ & $5.8 \pm 1.5$ & 0.938 & NS \\
\hline & ROM, degrees, adduction & $18.1 \pm 4.65$ & $18.3 \pm 3.2$ & 0.996 & NS \\
\hline & ROM, degrees, abduction & $17.1 \pm 2.9$ & $17.1 \pm 4.1$ & 0.999 & NS \\
\hline & $\begin{array}{l}\text { ROM, degrees, external } \\
\text { rotation }\end{array}$ & $26.3 \pm 4.2$ & $24.7 \pm 3.9$ & 0.450 & NS \\
\hline & $\begin{array}{l}\mathrm{ROM} \text {, degrees, internal } \\
\text { rotation }\end{array}$ & $24.1 \pm 4.9$ & $23.2 \pm 3.8$ & 0.885 & NS \\
\hline & VAS scale & $5.6 \pm 1.8$ & $6.3 \pm 1.9$ & 0.517 & NS \\
\hline & $\begin{array}{l}\text { Intensity of pain on the } \\
\text { Laitinen scale }\end{array}$ & $2.1 \pm 0.7$ & $2.3 \pm 0.7$ & 0.610 & NS \\
\hline & $\begin{array}{l}\text { Frequency of pain on the } \\
\text { Laitinen scale }\end{array}$ & $2.1 \pm 0.7$ & $2.1 \pm 0.8$ & 0.983 & NS \\
\hline & $\begin{array}{l}\text { Application of painkillers } \\
\text { on the Laitinen scale }\end{array}$ & $1.5 \pm 0.7$ & $1.9 \pm 0.7$ & 0.070 & NS \\
\hline \multirow{10}{*}{$\begin{array}{l}\text { Post- } \\
\text { treatment }\end{array}$} & ROM, degrees, flexion & $71.0 \pm 16.45$ & $68 \pm 15.5$ & 0.860 & NS \\
\hline & ROM, degrees, extension & $8.8 \pm 1.2$ & $8.4 \pm 1.3$ & 0.657 & NS \\
\hline & ROM, degrees, adduction & $23.5 \pm 5.1$ & $22.9 \pm 3.1$ & 0.933 & NS \\
\hline & ROM, degrees, abduction & $23.0 \pm 4.1$ & $21.7 \pm 4.6$ & 0.627 & NS \\
\hline & $\begin{array}{l}\text { ROM, degrees, external } \\
\text { rotation }\end{array}$ & $31.0 \pm 4.3$ & $29.8 \pm 4.2$ & 0.718 & NS \\
\hline & $\begin{array}{l}\text { ROM, degrees, internal } \\
\text { rotation }\end{array}$ & $28.7 \pm 5.3$ & $28.0 \pm 4.2$ & 0.935 & NS \\
\hline & VAS scale & $3.3 \pm 1.7$ & $4.7 \pm 1.7$ & 0.0171 & S \\
\hline & $\begin{array}{l}\text { Intensity of pain on the } \\
\text { Laitinen scale }\end{array}$ & $1.0 \pm 0.5$ & $1.6 \pm 0.5$ & 0.0023 & $S$ \\
\hline & $\begin{array}{l}\text { Frequency of pain on the } \\
\text { Laitinen scale }\end{array}$ & $0.8 \pm 0.5$ & $1.3 \pm 0.7$ & 0.0385 & $S$ \\
\hline & $\begin{array}{l}\text { Application of painkillers } \\
\text { on the Laitinen scale }\end{array}$ & $0.6 \pm 0.5$ & $1.6 \pm 0.6$ & 0.0001 & $S$ \\
\hline
\end{tabular}

P-value = Probability $\quad$ S = Significant $\quad$ NS = Non-significant

questionnaire; the frequency of their occurrence $0.8 \pm 0.5$ (Group I) vs $1.3 \pm 0.7$ (Group II) and the use of painkillers $0.6 \pm 0.5$ (Group I) vs. $1.6 \pm 0.6$ (Group II).

\section{DISCUSSION}

A literature review indicated the key role of rehabilitation in the therapy of persons with degenerative disease of the hip joint [7]. Similar to all synovial joints, the hip joint is also exposed to slow degenerative processes which, by impairing the afferent conduction from the joint capsule mechanoreceptors, lead to a reduction in articular cohesion, thereby increasing the risk of injury (particularly in the elderly population). The degenerative process is facilitated and the articular imbalance becomes strengthened [19]. Along with age and worsening degenerative changes, the progressive changes in osteo- and arthrokinematics of the joint show some general trends, including, for example, a gradual reduction in the range of motion of the thigh relative to the pelvis and the accompanying pain syndromes [20]. Restrictions of this type were present in the subjects of this study. These observations are consistent with the findings of other authors [21]. Scientific reports do not give an unambiguous answer to questions about the effectiveness of physiotherapeutic procedures aimed at rehabilitating patients with degenerative changes of the hip joint. McNair et al. [5] propose further search for advanced and effective improvement programmes for patients with diagnosed degenerative changes of the hip joint. This is also in line with the convictions of the authors the presented study, and are particularly relevant in the context of the most recent scientific reports [22]. In addition, bearing in mind the fact that early diagnosis, even at the level of the articular cartilage and an implementation of an optimal treatment can prevent the old-age disability, and thus extend patients' autonomy [3], the present authors recognize a need to seek and develop a programme that would be appropriate and tailored to patients' individual needs, hence their interest in the influence of a 3-week specially prepared individual therapeutic programme on the level of the perceived intensity of pain, and the range of motion in patients with degenerative disease of the hip joint.

The analysed results of the study of the range of motion at the hip joint showed a significant improvement in all planes of movement after applying postisometric relaxation of muscles with a combined therapy (TENS+UD) in degenerative changes in the hip joint, as well as applying only postisometric relaxation of muscles. The effectiveness of manual therapy techniques is also confirmed by other authors, including Hoeksma et al. [14], who by comparing the effectiveness of manual therapy techniques with traditional active exercises indicated the greater effectiveness in improving the hip mobility, as well as a larger analgesic effect of the former procedure. In addition, a meta-analysis published in 2009 demonstrated a good (B) level of the strength of evidence proving the effectiveness of applying therapeutic exercises and manipulation in the treatment of osteoarthritis of the knee joint, and a limited (C) level of evidence proving the effectiveness of applying therapeutic exercises and manual therapy in the treatment of osteoarthritis of the hip joint [23]. The presented study proves that therapeutic programmes enriched with a combined therapy procedure results in achieving a greater analgesic effect in patients with degenerative changes of the hip. These observations are confirmed by other authors, including Taradaj et al. [24], who recognized the combined therapy (TENS+UD) as effective in reducing pain ailments accompanying osteoarthritis, while Certin et al. [25] point to the fact that the use of a physical stimulus allows an increase in the efficiency of performed exercises. The present authors suggest, however, that the use of a physical stimulus in the form of a combined therapy is justified only in cases in which the limitation of joint mobility is accompanied by pain syndromes. Obviously, in the vast majority of cases this is so; however, in a group of patients without these ailments the procedure based on the use of muscle energising techniques is sufficient. A literature review on prophylactic treatment for osteoarthritis of the hip joint allows the conclusion that there is still space for research on the effectiveness of physiotherapeutic procedures aimed at improving the quality of medical services, hence this study, apart from the cognitive value, also has a practical implication. 


\section{CONCLUSIONS}

1. Both therapeutic procedures positively influenced an improvement in mobility in all planes of movement, and in particular movements of these planes in the hip joint and the reduction in the perceived pain and frequency of its occurrence.

2. In order to enhance the analgesic activity in patients with degenerative changes of the hip joint in non-invasive treatment, it is recommended to include a physical stimulus in the form of a combined therapy treatment in a physiotherapeutic procedure involving muscle energising techniques.

\section{REFERENCES}

1. Masud T, Blundell A, Gordon AL, Mulpeter K, Roller R, Singler K, et al European undergraduate curriculum in geriatric medicine developed using an international modified Delphi technique. Age Ageing. 2014; 43(5): 695-702.

2.Lam R, Gallinaro A, Adleman J. Medical Problems Referred to a Care of the Elderly Physician: Insight for Future Geriatrics CME. Can Geriatr J. 2013; 16(3): 114-119.

3. McKenzie S, Torkington A. Osteoarthritis-management options in general practice. Aust Fam Physician. 2010; 39(9): 622-625.

4. Bello A, Ababio E, Atwi-Baffoe S, Seidu MA, Adjei DN. Pain, range of motion and activity level as correlates of dynamic balance among elderly people with musculoskeletal disorder. Ghana Med J. 2014; 48(4): 214-218.

5. McNair PJ, Simmonds MA, Boocock MG, Larmer PJ. Exercise therapy for the management of osteoarthritis of the hip joint: a systematic review. Arthritis Res Ther. 2009; 11: R98-106 doi: 10.1186/ar2743.

6.Zhang W, Nuki G, Moskowitz RW, Abramson S, Altman RD, Arden NK, et al. OARSI recommendations for the management of hip and knee osteoarthritis, III: changes in evidence following systematic cumulative update of research published through January 2009. Osteoarthritis Cartilage. 2010; 18(4): 476-499.

7. Fernandes L, Hagen K, Bijlsma J, Andreassen O, Christensen P, Conaqhan PG, et al. EULAR recommendations for the non-pharmacological core management of hip and knee osteoarthritis. Ann Rheum Dis. 2013; 72(7): 1125-1135.

8. Van Es PP, Luijsterburg PA, Dekker J, Koopmanschap MA, Bohnen AM, Verhaar JA, et al. Cost-effectiveness of exercise therapy versus general practitioner care for osteoarthritis of the hip: design of a randomized clinical trial. BMC Musculoskeletal Disord. 2011; 12: 232-238.

9. Moretti FA, Marcondes FB, Provenza JR, Fukuda TY, de Vasconcelos RA, Roizenblatt S. Combined therapy (ultrasound and interferential current) in patients with fibromyalgia: once or twice in a week? Physiother Res Int. 2012; 17(3): 142-149.

10. Almeida TF, Roizenblatt S, Benedito-Silva AA, Tufik S. The effect of combined therapy (ultrasound and interferential current) on pain and sleep in fibromyalgia. Pain. 2003; 104(3): 665-672.
11. Grymel-Kulesza E, Polak A, Kubacki J, Skrzypek-Poloczek B, Król P. The effect of a multi-modality therapy including active exercises, classic massage, cryotherapy, and a combination of ultrasound and electrical stimulation on rotator cuff injuries. Fizjot Pol. 2007; 2(4): 107-123.

12. Itoh K, Hirota S, Katsumi Y, Ochi H, Kitakoji H. A pilot study on using acupuncture and transcutaneous electrical nerve stimulation (TENS) to treat knee osteoarthritis (OA). Chin Med. 2008; 3: 2 doi: $10.1186 / 1749-8546-3-2$.

13. Farina S, Casarotto M, Benelle M, Tinazzi M, Fiaschi A, Goldoni M, et al. A randomized controlled study on the effect of two different treatments (FREMS AND TENS) in myofascial pain syndrome. Eura Medicophys. 2004; 40(4): 293-301.

14. Hoeksma HL, Dekker J, Ronday HK, Heering A, Van der Lubbe N, $\mathrm{Vel} \mathrm{C}$, et al. Comparison of manual therapy and exercise therapy in osteoarthritis of the hip: a randomized clinical trial. Arthritis Rheum. 2004; 51(5): 722-729.

15. French HP, Cusack T, Brennan A, White B, Gilsenan C, Fitzpatrick $\mathrm{M}$, et al. Exercise and manual physiotherapy arthritis research trial (EMPART): a multicentre randomized controlled trial. BMC Musculoskeletal Disord. 2009; 10: 9 doi:10.1186/1471-2474-10-9.

16. Gould D, Kelly D, Goldstone L, Gammon J. Examining the validity of pressure ulcer risk assessment scales: developing and using illustrated patient simulations to collect the data information point: Visual Analogue Scale. J Clin Nurs. 2001; 10(5): 697-706.

17. Laitinen J. Acupuncture and transcutaneous electrical nerve stimulation in the treatment of chronic sacrolumbalgia and ischialgia. Am J Chin Med. 1976; 4(2): 169-175.

18. Russe OA, Gerhardt J. International SFTR method of measuring and recording joint motion ISOM, international standard orthopedic measurements. Bern: Hans Huber Publishers; 1975.

19. Lee D. Obręcz biodrowa. Badanie i leczenie okolicy lędźwiowomiedniczno-biodrowej [The pelvic girdle. Examination and treatment of the lumbopelvic area]. DB Publishing, Warszawa 2001. Polish.

20. Nonaka H, Mita K, Watakabe M, Akataki K, Suzuki N, Okuwa T, et al. Age-related changes in the interactive mobility of the hip and knee joints: a geometrical analysis. Gait Posture. 2002; 15(3): 236-243.

21. Holla JF, Steultjens MP, van der Leeden M, Roorda LD, Bierma-Zeinstra $\mathrm{SM}$, den Broeder AA, et al. Determinants of range of joint motion in patients with early symptomatic osteoarthritis of the hip and/or knee: an exploratory study in the CHECK cohort. Osteoarthritis Cartilage. 2011; 19(4): 411-419.

22. Hernández-Molina G, Reichenbach S, Zhang B, LaValley M, Felson DT. Effect of Therapeutic Exercise for Hip Osteoarthritis Pain: Results of a Meta-Analysis. Arthritis Rheum. 2008; 59(9): 1221-1228.

23. Brantingham JW, Globe G, Pollard H, Hicks M, Korporaal C, Hoskins W. Manipulative therapy for lower extremity conditions. Expansion of literature review. J Manipulative Physiol Ther. 2009; 32(1): 53-71.

24. Taradaj J, Feliksik M, Franek A, Błaszczak E. Terapia skojarzona (TENS+UD) w leczeniu bólów krzyża [The combined therapy (TENS+UD) in the treatment of lower back pains]. Rehabil Prakt. 2008; 4: 38-39. Polish.

25. Certin N, Aytar A, Atalay A, Akman MN. Comparing hot pack, shortwave diathermy, ultrasound, and TENS on isokinetic strength, pain, and functional status of woman with osteoarthritic knees: a single-blind, randomized, controlled trial. J Phys Med Rehabil. 2008; 87: 443-451. 